\title{
Pemanfaatan Iklan Layanan Masyarakat (ILM) Guna Meningkatkan Hasil Penghimpunan Dana Organisasi Nirlaba Lembaga Amil Zakat (LAZ) Solopeduli-Surakarta
}

\author{
Andrik Purwasito ${ }^{1}$ \\ Universitas Sebelas Maret, andrikpurwasito@staff.uns.ac.id \\ Erwin Kartinawati ${ }^{2}$ \\ Universitas Sahid Surakarta, erwinpurwasito@gmail.com
}

\begin{abstract}
Abstrak
Sebagai organisasi nirlaba, Yayasan Solopeduli Ummat memunyai visi percontohan dalam memberdayakan dan memandirikan umat, dengan misi kemanusiaan, seperti menghadirkan program solutif untuk masyarakat miskin. Salah satu aksi organisasi ini adalah penghimpunan dana dari masyarakat, yang ditangani oleh Lembaga Amil Zakat (LAZ). Dana terhimpun, digunakan untuk membantu masyarakat tertimpa musibah, seperti orang sakit, korban banjir, pengungsi bencana alam, pembangunan dan biaya sekolah gratis bagi masyarakat miskin, klinik kesehatan dan ambulans gratis, dan lain sebagainya. Di era milenial ini, LAZ Solopeduli ingin melakukan transformasi digital agar target-target lembaga dapat tercapai secara optimal. Guna membantu tercapainya tujuan ini, kami melakukan pelatihan videografi dalam bentuk Iklan Layanan Masyarakat (ILM). Pelatihan ini diarahkan untuk meningkatkan kompetensi para insan di Yayasan Solopeduli, khususnya di LAZ, agar menguasai teknologi informasi dalam bentuk pembuatan dan penerbitan videografi, khususnya video untuk promosi dan penghimpunan dana dari masyarakat. Pelatihan ini memiliki output mencetak video-maker dalam bidang ILM, khususnya teoritisasi ILM, take camera, editing and uploading video. Metode pelatihan dilakukan beberapa tahap: (1) Tahap teoritisasi; (2) FGD gagasan pembuatan konten; (3) Penggunaan kamera dan pengambilan gambar; (4). Editing produk audio visual; (5). Evaluasi; (6). mengunggah video di media sosial. Hasilnya, para insan Solopeduli mampu membuat ILM sendiri, sehingga memunyai kemampuan untuk mempromosikan lembaga sosial tersebut dengan standar digital memadai. Memunyai kemampuan membuat videografi untuk berbagai kepentingan, khususnya program penghimpunan dana yang memang dibutuhkan untuk disalurkan ke masyarakat membutuhkan, juga menjadi hasil dari kegiatan ini.
\end{abstract}

Kata Kunci: Solopeduli, Videografi, ILM, Penghimpunan Dana, Promosi.

\begin{abstract}
As a non-profit organization, Yayasan Solopeduli Ummat in Surakarta has vision in an empowering people, with a humanitarian mission, such as presenting a solution program for the poor, from birth to death. One of the actions of this organization is raising fund from the community, which is handled by the Amil Zakat Institution (LAZ). Collected fund is used to help poor people, such as sick persons, flood victims, natural disaster refugees, construction and free schools for the poor, free ambulance and health clinics, and so on. In this millennium, LAZ Solopeduli wants to carry out a digital transformation so the target of that institutional can be
\end{abstract}


achieved optimally. To help achieve this goal, we conducted videography training for Public Service Ads (ILM). This training aims to increase the competence of employees in Solopeduli, especially at LAZ, so they can master information technology in the form of the creation and publication of videography, especially videos for promotion and fund raising from the public. This training has the output, that are creating video-makers in the ILM field, specifically the theorization of ILM, camera take, video editing and uploading on social media, such as websites and youtube. The training method carried out in several stages: (1) Theoretical stage; (2) FGD on the idea of content creation; (3) Using camera and shooting; (4). Editing audio-visual products; (5). Evaluation; (6). Uploading videos on social media. Results of this training are, first, Solopeduli's employees able to make their own videography, so they have the ability to promote these social institutions with adequate digital standards. Second, the employees also have the ability to make videography for various purposes, especially in fund raising programs that are needed to be distributed to the people in need.

\section{Keywords : Solopeduli, Videography, Public Service Ads, Fund Rising, Promotion.}

\section{Pendahuluan}

Bentuk-bentuk kegiatan sosial yang ditujukan membantu meringankan beban masyarakat kurang mampu, memiliki peran sangat besar dalam membantu pemerintah mengentaskan kemiskinan. Pemerintah juga memiliki kewajiban sebagaimana diamanahkan UUD 1945 untuk menangani fakir miskin dan anak-anak telantar (Pasal 34 ayat 1). Namun beban itu bukan persoalan yang mudah dan cepat untuk ditangani. Oleh karenanya, keberadaan lembaga atau organisasi yang bergerak di bidang kemanusiaan sangat dibutuhkan. Salah satu organisasi sosial yang bergerak dalam bidang kemanusiaan yakni Yayasan Solopeduli Ummat atau lebih dikenal dengan sebutan Solopeduli. Organisasi nirlaba ini hadir saat masyarakat Indonesia dilanda krisis moneter tahun 1998. Krisis moneter saat itu menyebabkan perekonomian terpuruk, terjadi banyak Pemutusan Hubungan Kerja (PHK) hingga menyebabkan banyak pengangguran dan angka kemiskinan meningkat. Melihat kondisi memprihatinkan di atas, Solopeduli hadir untuk menumbuhkan kepedulian kepada sesama, terutama kepada masyarakat dhuafa yang paling menderita akibat krisis. Kepedulian tersebut digalang melalui dana ZISWAF (Zakat, Infaq, Shadaqah, Wakaf, serta dana sosial lainnya yang halal dan legal, baik dari dari perseorangan maupun perusahaan/lembaga). Hasil penggalangan atau penghimpunan dana, selanjutnya diwujudkan dalam program-program sosial yang inovatif dan solutif sesuai kebutuhan masyarakat (https://www.solopeduli.com/sejarahsolopeduli.html, akses 27 April 2019, Pkl 16.36 wib).

Program-program yang dimiliki Solopeduli adalah Klinik Rawat Inap di Kota Solo dan Sukoharjo, Pesantren Gratis di Klaten, Sekolah Menengah Kejuruan gratis di Solo, Lembaga Keterampilan dan Pelatihan Gratis di Sukoharjo, 6 Ambulan Gratis di Jawa Tengah dan 1 di Aceh, serta Mobil Layanan Ummat di Semarang. Program lainnya yakni beasiswa bagi siswa sekolah dasar (SD) kurang mampu hingga perguruan tinggi, berbagi hewan kurban, aksi tanggap bencana, pelestarian alam serta penanganan anak yatim. Semua itu, dibiayai murni dari dana yang dihimpun dari masyarakat. Upaya penghimpunan selama ini lebih banyak dilakukan melalui cara 
konvensional yakni dari mulut ke mulut, dan promosi program melalui leaflet, spanduk dan juga website. Bentuk penghimpunan dan peningkatan dana dari masyarakat masih dinilai sangat sederhana sehingga dirasa masih kurang maksimal. Sehubungan dengan hal itu, diperlukan upaya inovatif terutama di era milenial saat ini. Pemaksimalan tehnologi informasi sangat dibutuhkan dan akan sangat membantu tercapainya upaya peningkatan penghimpunan dana dari masyarakat. Upaya kreatif dibutuhkan agar masyarakat menjadi lebih tertarik atau terketuk hati untuk menyalurkan sebagian harga bendanya melalui lembaga ini, disamping untuk menaikkan kredibilitas organisasi agar kepercayaan masyarakat meningkat (hasil wawancara dengan Direktur Pengembangan Sumber Daya Manusia Solopeduli, Endri Kusumaratih). Sehubungan dengan persoalan di atas maka kami melakukan kegiatan pengabdian kepada masyarakat, dalam bentuk pelatihan dan pendampingan dalam membuat Iklan Layanan Masyarakat (ILM) format audio visual (videography). ILM merupakan salah satu bentuk kreatif yang dapat dilakukan untuk menarik perhatian masyarakat, yang pada akhirnya mampu menggiring dan menggerakkan orang mengambil tindakan yang menguntungkan pihak pembuat iklan (Durianto, 2003). Pada konteks ini, maka iklan dibuat bermuara pada tindakan masyarakat untuk menyalurkan dana sosial mereka melalui Yayasan Solopeduli. Pelatihan dan pendampingan pembuatan iklan ini kami nilai penting agar iklan yang dibuat tidak sekadar berhenti menjadi sebuah produk namun memiliki dampak. Dampak apa yang diharapkan? Yakni dampak yang berupa respons positif dari masyarakat. Pendampingan dan pelatihan diberikan dengan menyertakan pemahaman mengenai prinsip-prinsip ilmu periklanan dan videografi.

Pelatihan membuat iklan layanan masyarakat bagi organisasi nirlaba ini bertujuan meningkatkan keterampilan para karyawan Yayasan Solopeduli, utamanya yang terkait dengan program penghimpunan dana seperti bagian Humas, promosi, dan fund riser. ILM yang dibuat para karyawan Solopeduli diharapkan dapat digunakan sebagai sarana promosi meningkatkan kepercayaan publik terhadap lembaga, dan atau menggerakkan hati masyarakat untuk menyisihkan sebagian harta mereka melalui organisasi ini untuk kegiatan sosial. Melalui kegiatan ini pula, diharapkan para karyawan Solopeduli dapat melakukan promosi mandiri melalui kanal dipunya, mengenai berbagai kegiatan dilakukan, agar lebih dikenal oleh publik, tanpa harus mengeluarkan anggaran untuk kebutuhan publikasi di media massa.

Dari kegiatan ini, manfaat yang dapat diambil para karyawan LAZ Solopeduli adalah kemampuan dan keterampilan dalam membuat iklan layanan masyarakat. Dari iklan hasil produksi internal tersebut, selain berpotensi dapat meningkatkan jumlah himpunan dana, juga dapat menghemat atau bahkan memangkas anggaran promosi untuk media massa.

Iklan secara sederhana dapat didefinisikan sebagai pesan yang menawarkan suatu produk ke masyarakat lewat suatu media (Triadi\&Bharata, 2010). Iklan merupakan bentuk komunikasi berbayar yang dilakukan individu atau perusahaan dengan tujuan memengaruhi orang untuk berperilaku atau mengikuti sebagaimana informasi disampaikan. Tujuan iklan adalah membujuk untuk membeli atau menggunakan layanan jasa pengiklan (Green, 2012). Iklan juga menginformasikan ke masyarakat 
mengenai suatu kegiatan, ide atau produk. Kebanyakan iklan didesain untuk menjual produk atau jasa (Raum, 2015). Dari beberapa definisi di atas dapat disimpulkan jika iklan adalah bentuk kegiatan komunikasi atau penyampaian pesan dengan tujuan memengaruhi orang untuk membeli, berperilaku, atau melakukan sesuatu sebagaimana disampaikan dalam informasi. Di era milenial seperti sekarang, pemahaman tentang iklan dapat diperluas dimana iklan tidak harus berbayar berkat kehadiran internet, sehingga pengiklan dapat menggunakan saluran mereka sendiri (website atau media sosial dimiliki, seperti Youtube, Instagram, Facebook, dsb). Titik tekan dari iklan adalah strategi mempengaruhi pikiran, perasaan, dan tindakan konsumen (Moriarty; Mitchel,Wells, 2009).

Tak hanya membujuk atau memengaruhi orang untuk membeli atau bertindak sesuai keinginan pengiklan, iklan juga memiliki fungsi lain (Triadi\&Batara, 2013). Fungsi itu yakni memberikan informasi mengenai suatu produk, menciptakan kesan atau image baik, memuaskan keinginan (orang ingin mengetahui kandungan gizi/vitamin suatu hal, harga), alat komunikasi, sekaligus untuk menjaring khalayak. Jenis iklan dibedakan menjadi dua berdasar tujuannya yaitu iklan komersil dan iklan layanan masyarakat. Iklan komersil jelas bertujuan membujuk orang untuk membeli produk atau melakukan sesuatu, yang orientasinya pada keuntungan pribadi/kelompok/ organisasi atau suatu perusahaan. Satunya adalah iklan layanan masyarakat (ILM). Iklan ini biasanya digunakan untuk sesuatu yang sifatnya sosial seperti penggalangan dana atau kegiatan amal (Green, 2012). Selain untuk kegiatan amal, ILM juga bisa berbentuk informasi yang tujuannya mengubah perilaku masyarakat, misalnya ajakan berhenti merokok dan berkendara dengan aman (Raum, 2015).

Untuk mencapai tujuannya, iklan dapat disampaikan dengan banyak alat atau media. Iklan yang penyampaian pesannya menggunakan media massa seperti koran, radio, televisi, website dan sejenisnya disebut 'above the line'. Iklan ini disampaikan melalui media yang dapat dilihat atau dijangkau masyarakat banyak, sedangkan iklan yang menjangkau kalangan khusus (pribadi) disebut ' below lhe line'. Alat digunakan seperti surat elektronik, surat, dan gawai (Green, 2012).

Agar dapat tepat sasaran, iklan harus dikemas secara baik. Iklan yang baik adalah iklan yang pesannya dibuat/dirancang untuk memenuhi kebutuhan khalayak yang sudah ditentukan, memiliki tujuan spesifik, dan ditempatkan di media yang paling efektif dalam menjangkau khalayak. Iklan juga harus memiliki konsep kreatif sehingga dapat menarik perhatian dan ingatan publik. Iklan juga harus menggunakan Teknik eksekusi pesan yang tepat (Jaiz, 2014). Sementara Renald Kasali (1993) menyebut kriteria iklan yang bagus harus memenuhi rumus AIDCA : attention (perhatian); interest (minat); desire (hasrat/kebutuhan); conviction (keinginan); dan action (tindakan). Attention yaitu keharusan suatu iklan untuk mampu menarik perhatian sasaran. Interest berkaitan dengan kemampuan merangsang konsumen agar mau membaca, mendengarkan, melihat pesan-pesan disampaikan. Desire berupa kemampuan menggerakkan keinginan orang untuk memiliki atau menikmati produk. Conviction artinya iklan harus mampu menciptakan kebutuhan calon pembeli. Action adalah kemampuan membujuk orang untuk membeli. 
Iklan terbukti menjadi cara ampuh dalam mengenalkan produk ke masyarakat serta upayanya dalam mendongkrak tingkat penjualan. Sunny Delight, salah satu produk minuman di Inggris, misalnya, pernah menjadi tren atau bagian gaya hidup di kalangan anak-anak. Produk ini menjadi minuman paling laris nomor tiga di negara itu hanya dalam waktu singkat yakni tidak ada satu tahun. Tahun sebelumnya, merek itu bahkan disebut sebagai merek yang sama sekali tidak pernah orang kenal bahkan dengar pun tidak. Masyarakat begitu terpengaruh karena minuman ini menyuarakan kandungan sejumlah vitamin dalam produk sehingga membuat para orangtua berpikir jika minuman ini menyehatkan dibanding soft drink. Padahal badan pengawas makanan setempat menyatakan kandungan minuman ini tak beda dari minuman jenis soft drink lainnya, yang merupakan hasil sulingan gula putih. Produk ini menyerang sekolah-sekolah dengan menjadi sponsor utama sejumlah kegiatan olahraga maupun Asosiasi Basket Inggris (Sardar, 2008). Contoh kasus tersebut memperlihatkan kepada kita betapa iklan memiliki kekuatan luar biasa dalam memengaruhi keputusan atau daya beli masyarakat. Kemasan atau bagaimana produk/jasa dikenalkan ke publik juga menjadi faktor penting dalam pengambilan keputusan masyarakat (Lado Cousté, Martos-Partal, Martínez-Ros, 2012). Dalam konteks ini maka Solopeduli harus mampu mengemas iklannya secara menarik agar mampu menarik perhatian publik, yang kemudian mampu menggerakkan minat mereka untuk menggunakan jasa dari LAZ Solopeduli.

Iklan bekerja dengan tidak menghasilkan pengaruh secara langsung namun efek tertunda. Iklan bekerja di bawah alam sadar yang sewaktu-waktu bisa muncul ke permukaan karena melalui proses berulang. Melalui sajian yang menarik, iklan mampu meninggalkan bekas di benak audiens (Moriarty, Mitchel, Wells, 2009), (Suwardi, 2006). Dalam konteks penghimpunan dana dari masyarakat, ILM dapat menjadi sarana ampuh, selama memenuhi syarat-syarat seperti tersebut di atas, dimulai dari kemampuan menarik perhatian hingga menggerakkan publik untuk berderma melalui Solopeduli berkat iklan dibuat.

Iklan bisa dibuat dalam bentuk cetak, audio, maupun audio visual. Videografi berkenaan dengan tehnik membuat karya dalam bentuk audio visual (video). ILM dalam bentuk audio visual dipilih sebagai materi pelatihan dan pendampingan karena produk audio visual diyakini memiliki pengaruh yang lebih besar karena kelebihan dimiliki. John N Bailey dalam artikel berjudul Internal Communication Media (1983) menyebut, media audio visual mampu menghadirkan ide yang melibatkan gerakan, yang tidak dapat digambarkan secara fisik melalui media cetak. Media audio visual mengkombinasikan pengaruh dari visual, suara, drama, gerakan, warna dan musik Media audio visual juga mampu menarik perhatian khalayak secara terus menerus meski waktunya Panjang, mampu mengetengahkan peristiwa secara lebih nyata sehingga dapat lebih dipercaya (seeing is believing) (Suwardi, 2000). Tak mengherankan jika survey Nielsen selama beberapa dekade terahir membuktikan jika televisi adalah primadonanya masyarakat, dibanding jenis media lain.

Kini, dengan kecanggihan tehnologi berbasis internet, produk audio visual tidak hanya dapat ditayangkan di televisi namun juga jenis media lain baik media luar 
ruang (videotron), ataupun website, serta media sosial seperti youtube, instagram, facebook, dan seterusnya. Para pengiklan yang sebelumnya lebih banyak menyasar ke televisi , sudah mempertimbangkan internet sebagai bagian dari media beriklan. Di tahun 2010 saja, pertumbuhan iklan dalam bentuk audio visual, di dunia maya ini telah menembus angka tiga miliar. Tren iklan audio visual yang dibuat dalam waktu singkat ditegaskan mampu menarik perhatian audiens hingga memunculkan model iklan sekuel atau disebut webeisodes yakni iklan dalam bentuk seri (episode). (Shimp, 2010).

\section{Metode}

Khalayak sasaran dalam pengabdian ini adalah para karyawan dan pimpinan di unitunit Solopeduli yang terkait dengan bidang penghimpunan dana (LAZ). Metode digunakan dalam kegiatan pengabdian ini berupa pelatihan dan praktik langsung, yang kesemuanya meliputi enam tahap. Pertama tahap teoritisasi; (2) forum group discussion (FGD) gagasan konten dan pembuatan; (3) Tahap penggunaan kamera dan pengambilan gambar; (4). Tahap editing produk audio visual; (5). Evaluasi; (6). Tahap mengunggah video.

Tahap pelatihan merupakan tahap pemberian materi kepada peserta mengenai konsep iklan; peran dan fungsi iklan; pengaruh iklan; dan jenis-jenis iklan; serta materi tentang produksi karya audio visual (berupa teknis pengambilan gambar bergerak dan editing video). Sementara metode praktik langsung adalah implementasi pascapemberian materi (teoritisasi), yakni mempraktikkan pengetahuan didapat dalam bentuk produksi karya, dimulai dari pembuatan konsep ILM, membuat perencanaan produksi, praktik syuting dan edit video, serta terakhir adalah unggah video ILM produksi karya para peserta di kanal Youtube Solopeduli.

\section{Hasil dan Pembahasan}

Kegiatan pengabdian ini dilakukan dalam jangka waktu satu tahun di 2019, didanai Ristek Dikti melalui program kreatifitas masyarakat (PKM). Seperti disebutkan di atas, kegiatan ini meliputi enam tahap yang akan dijelaskan sebagaimana berikut :

Pertama adalah tahap teoritisasi. Pada tahap ini, peserta yang terdiri dari 40 orang diberikan pemaparan materi tentang dasar-dasar iklan, tehnik pembuatan produk audio visual, serta pemaksimalan media sosial sebagai ajang promosi untuk penghimpun dana bagi organisasi nirlaba. Materi atau teoritisasi iklan disampaikan oleh penulis/pengabdi dengan diperkaya pengalaman pengabdi dalam membuat produk audio visual serta content creator. Pada tahap ini disampaikan pula berkenaan cara pengambilan gambar/video, dan trik sukses menggaet viewer, visitors melalui saluran Youtube. Kegiatan teoritisasi dapat dilihat pada gambar 1 di bawah ini. Fakta di lapangan menyebutkan bahwa hampir semua dari para peserta pelatihan sangat minim dalam penguasaan dasar tentang iklan. Hal ini dikarenakan latar belakang pendidikan dan pemahaman yang kurang mengenai perlunya iklan, berikut kekuatan iklan sebagai alat promosi. Pemahaman peserta mengenai kekuatan media sebagai alat penyebaran pesan yang cepat dan massif, sehingga berpotensi memikat 
keputusan publik, juga masih kurang. Oleh karena itu, materi mengenai konsep dasar iklan dan kekuatan media, diperlukan sebagai dasar perlunya produk iklan dibuat.

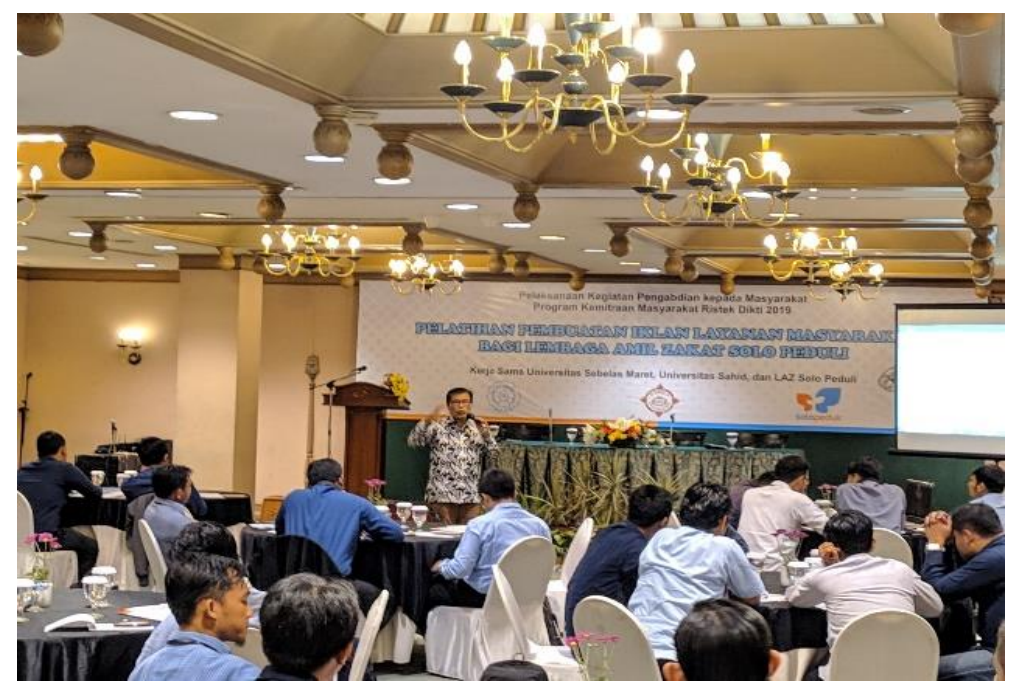

Gambar 1. Tahap teoritisasi berupa pemberian materi kepada peserta mengenai dasar-dasar iklan dan pembuatan karya audio visual.

Tahap kedua yakni FGD konsep dan materi iklan. Usai mendapat teori tentang iklan dan produk audio visual, pada tahap ini, para peserta dibagi ke delapan kelompok. Pembagian kelompok melalui proses penyaringan berdasar data isian mengenai bidang peminatan serta keahlian dimiliki, dengan menggunakan google form. Isian ini untuk memetakan kemampuan dan minat peserta agar merata di tiap-tiap kelompok. Dalam artian, tidak ada kelompok yang memiliki kemampuan dan minat sama, dikumpulkan dalam satu tim, yakni peminatan sebagai kameramen, sutradara, pemain, pembuat naskah, dan editor video. Setiap kelompok, melakukan diskusi mengenai tema yang akan diambil kemudian dibuat konsep serta perencanaan mulai dari pra produksi, produksi, hingga pascaproduksi. Tahap FGD ini, setiap kelompok melakukan presentasi mengenai ide ILM berikut rancangan tentang teknis pelaksanaan di lapangan. Kelompok lain dan tim pelaksana pengabdian, memberikan masukan tentang konsep diajukan. Penjaringan ide dan masukan ini dibutuhkan untuk penyempurnaan konsep dan teknis produksi. Kegiatan FGD dapat dilihat pada gambar 2 dan 3.

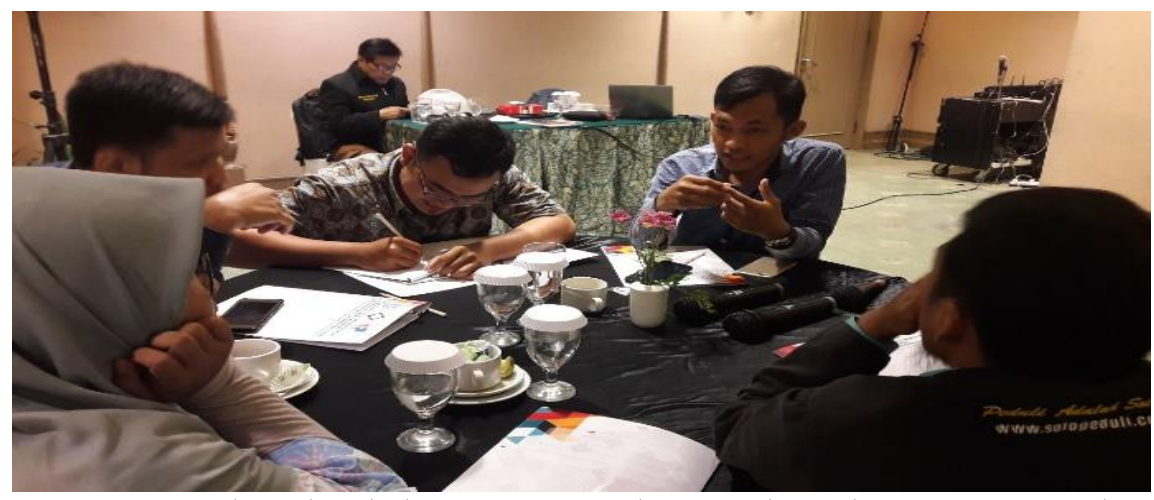

Gambar 2. Para peserta sedang berdiskusi mengenai konsep dan teknis ILM yang akan diproduksi. 


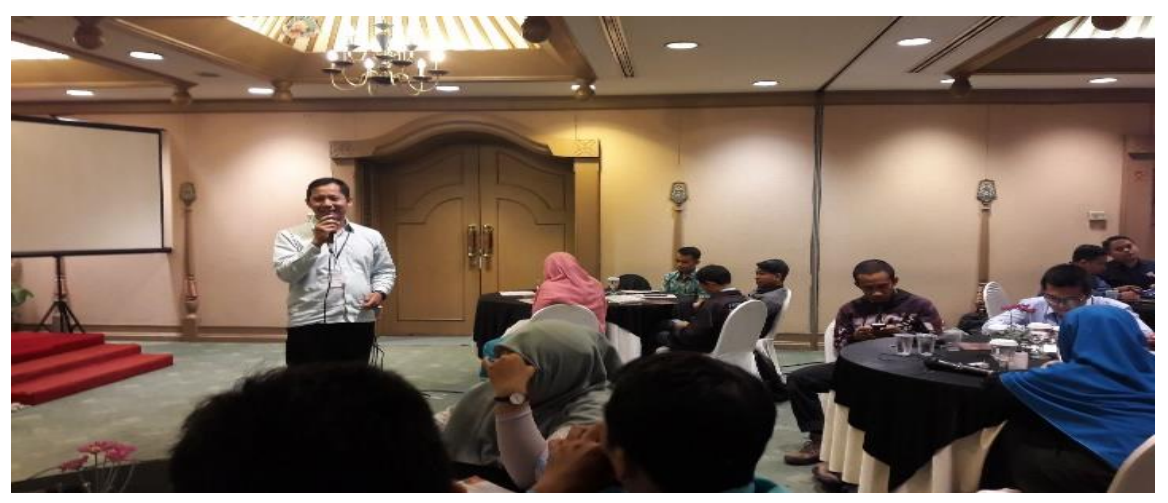

Gambar 3. Proses penjaringan ide dari audiens sekaligus presentasi konsep ILM dari para kelompok.

Tahap selanjutnya adalah tahap pengunaan kamera dan pengambilan gambar. Pada tahap ini, setiap kelompok terjun ke lokasi ditentukan sesuai setting cerita/ide iklan yang akan dibuat. Peserta diberi kebebasan dalam menentukan ide sekaligus pemain. Dalam arti, apakah cukup menggunakan anggota kelompok ataukah menambahkan tokoh lain, tergantung ide ditentukan. Beberapa kelompok tidak menggunakan anggota sebagai pemain dalam iklan karena mengambil realita di lapangan. Praktik penggunaan kamera sekaligus proses produksi untuk pengambilan gambar (syuting), dapat dilihat pada gambar 4,5,6 dan 7 .

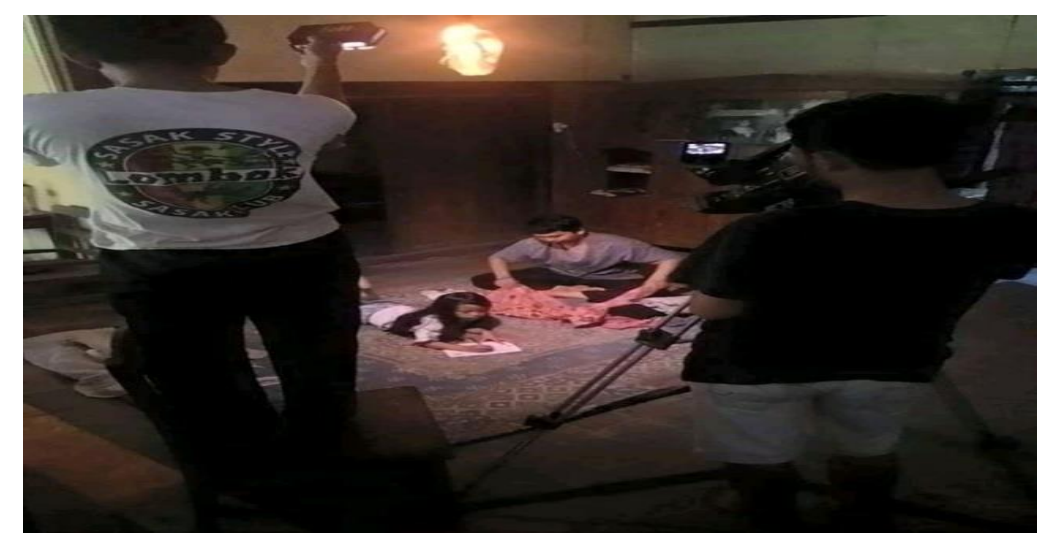

Gambar 4. Proses syuting untuk produk Iklan Layanan Masyarakat oleh peserta

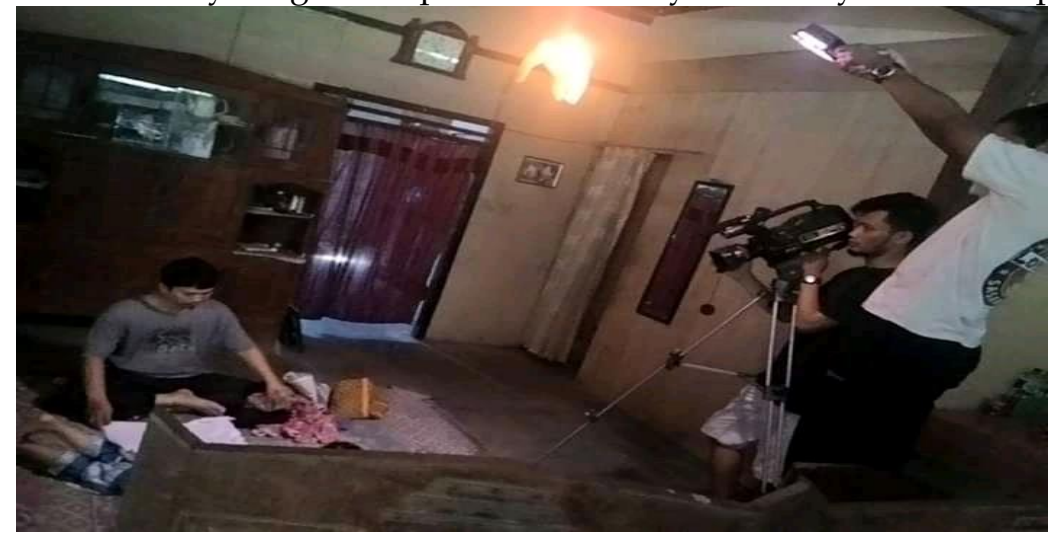

Gambar 5. Proses produksi ILM oleh peserta pelatihan 


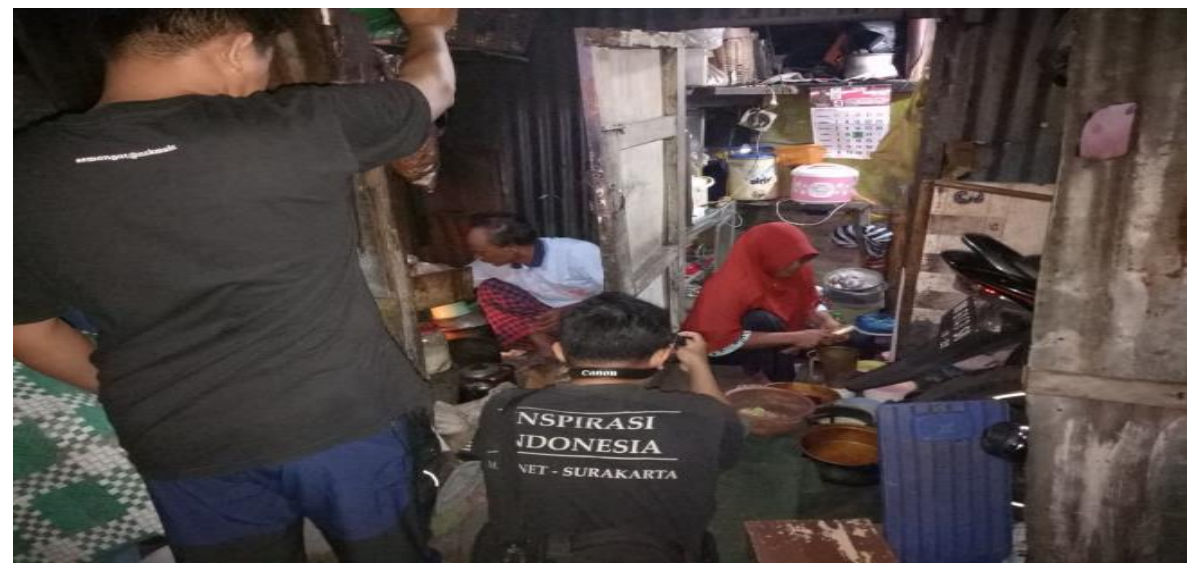

Gambar 6. Proses syuting untuk produk ILM oleh peserta.

Setelah syuting, tahapan selanjutnya adalah proses editing. Pada tahapan ini video yang telah diambil, diedit, membentuk sebuah ILM seperti direncanakan. Untuk keperluan editing, peserta diberikan materi tentang menggunakan software edit video yakni adobe premier. Tahap editing menyatukan antara video, suara, suara tambahan serta efek lain untuk menghasilkan tampilan yang menarik. Pada tahap ini, peserta masih diperkenankan mengambil kembali gambar di lapangan terutama bila video diambil kurang sesuai standar, mengalami masalah, atau dubbing ulang narasi (gambar 7 dan 8). Pada proses ini, pendamping sekaligus memberikan evaluasi mengenai kualitas pengambilan gambar, durasi, logika cerita, dan seterusnya. Permasalahan paling banyak ditemui adalah cara pengambilan sudut gambar dan waktu yang kurang tepat. Setting syuting juga menjadi hal yang paling banyak dijumpai dari hasil produksi pertama para peserta. Hal itu dapat dilihat dari alur cerita yang kurang logis, penyajian gambar/video yang jumping, under/over exposure dalam hal pencahayaan. Kebanyakan dari peserta masih terfokus pada isi iklan, namun setting lokasi belum diperhatikan. Setting lokasi sangat diperlukan untuk memaksimalkan penyampaian pesan ke public, sekaligus sebagai soft promo kepada pemirsa.

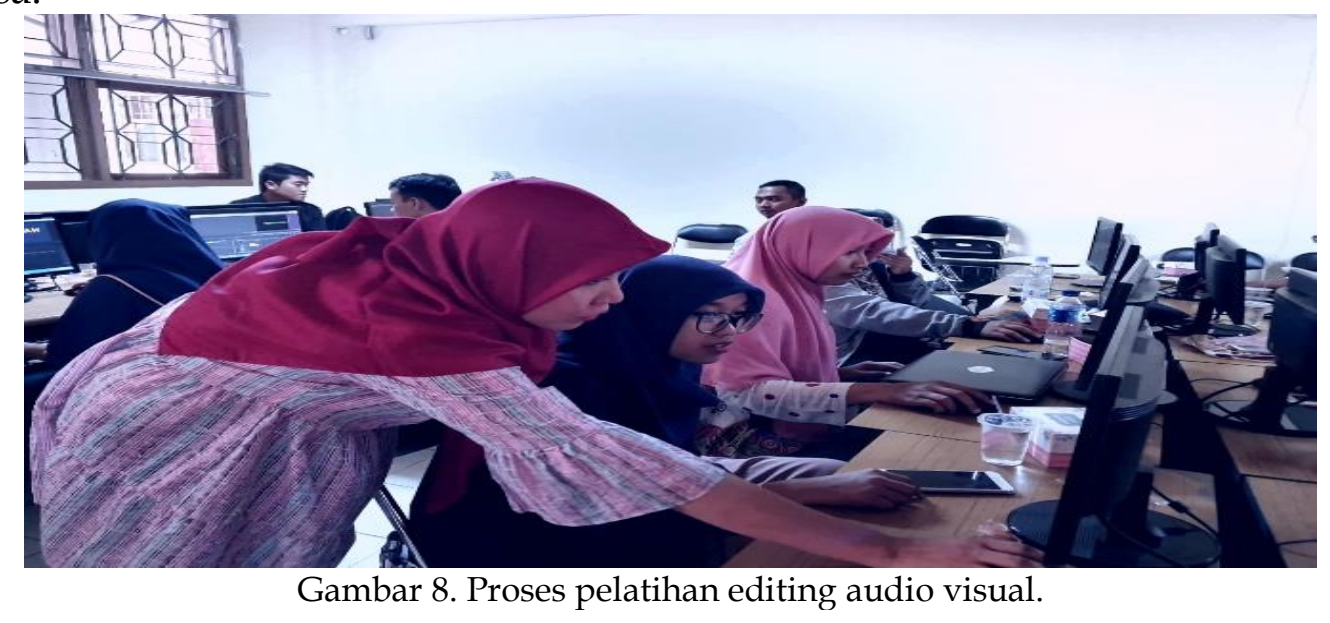




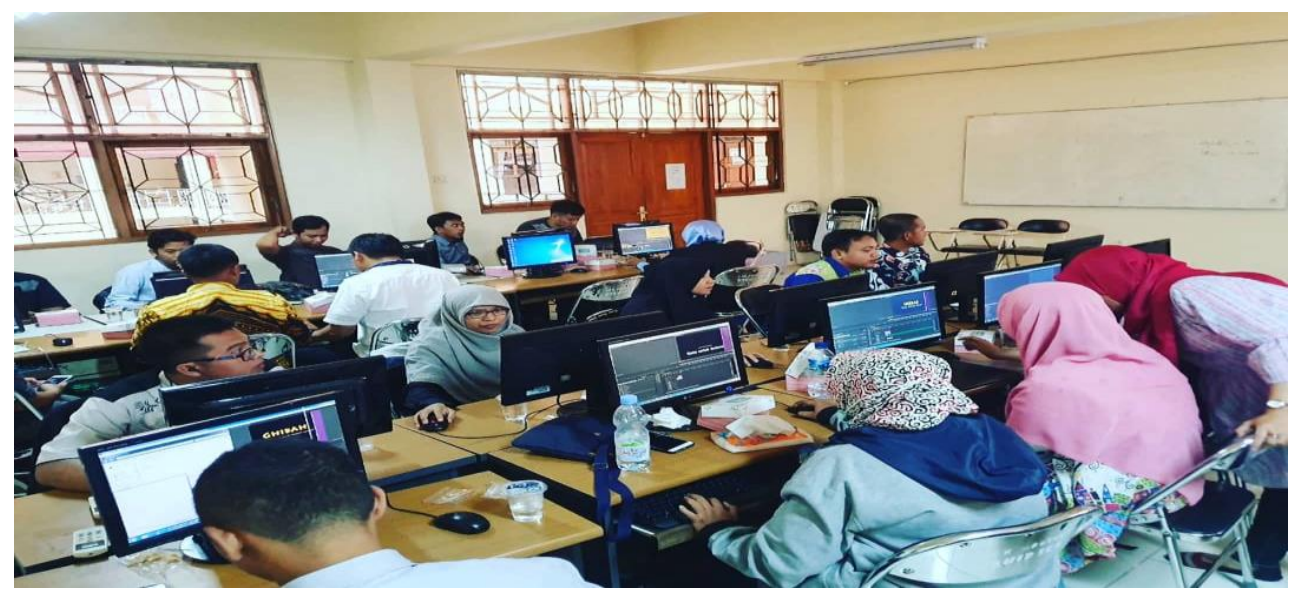

Gambar 9. Praktik mengedit video dengan adobe premier

Setelah dilakukan proses editing, tahapan selanjutnya adalah tahap evaluasi. Pada tahap ini, semua kelompok terbagi, mempresentasikan hasil karya mereka di depan tim pelaksana dan juga anggota lainnya. Tahap evaluasi, memastikan jika karya peserta telah siap untuk dipublikasikan ke publik, melalui berbagai media dimiliki, terutama website dan saluran youtube yayasan, serta akun-akun media sosial peserta. Dengan adanya pengunggahan ini otomatis membuat tampilan website atau akun terus terbarukan, disamping banyaknya informasi yang bisa dipilih oleh masyarakat, saat mengakses akun Solopeduli.

Berikutnya adalah tahap pengunggahan video ILM. Tahap pengunggahan video merupakan tahap akhir dimana karya peserta dapat dilihat oleh umum. Tahap ini menandai jika upaya promosi telah dilakukan. Pengunggahan video dilakukan oleh admin yayasan, dalam hal ini bagian yang menangani program tehnologi dan informasi (TI).

\section{Simpulan dan Rekomendasi}

Secara umum kegiatan pengabdian kepada masyarakat ini terselenggara dengan baik. Hal ini dikarenakan antusiasme peserta yang cukup tinggi yang mengikuti semua tahap dari awal hingga akhir. Proses kegiatan ini mendapat dukungan luar biasa dari peserta karena merasa mendapatkan sesuatu yang memberikan manfaat bagi kemajuan organisasi, yang tak hanya dapat digunakan untuk membantu meningkatkan fund rising dari masyarakat melalui ILM, namun juga dapat melalui bentuk lain, yakni berita dan produk pembelajaran daring. Dari pelatihan ini, para peserta mendapatkan kemampuan dalam membuat konsep dan perencanaan iklan layanan masyarakat, menggunakan kamera dan mengambil gambar sesuai standar, mengedit video, serta mengunggahnya melalui saluran tersedia, dengan memperhatikan potensi click viewer/visitors.

Pelatihan ini diharapkan merupakan langkah awal bagi insan Solopeduli untuk berkarya dan terus berkreativitas sehingga jumlah ILM dihasilkan terus bertambah, dan terbarui secara kontinyu dan konsisten, baik dari segi tema maupun waktu pengunggahan. Tema yang konsisten mempermudah audiens dalam memberikan identifikasi sekaligus penetrasi pasar yang baik di benak publik. Konsistensi dalam 
waktu pengunggahan untuk menjaga agar tidak ada rentang waktu yang terlalu jauh antar satu dengan lainnya, sehingga masyarakat secara terus menerus mendapatkan hal baru/ update. Konten website atau saluran media yang terus terbarukan, jelas lebih menarik dibanding channel yang tidak sama sekali/lama/tidak konsisten dalam pemostingan informasi. Yang tidak kalah penting adalah perlunya pemahaman mengenai etika pariwara dan atau etika media sehingga setiap karya yang terpublikasikan, bebas dari hal-hal berbau kesukuan, agama dan ras, kekerasan serta sadisme, pornografi, dan lain sejenisnya. Konten diunggah tidak hanya bermuara pada hal yang sifatnya menghibur demi menarik perhatian publik, namun harus mengedepankan hal-hal yang sifatnya mendidik, disamping sesuatu yang informatif.

\section{Acknowledgements}

Kegiatan pengabdian kepada masyarakat ini terselenggara berkat dukungan dana dari Ristek Dikti, melalui Program Kemitraan Masyarakat tahun 2019, dan kerja sama dengan Yayasan Solopeduli.

\section{Daftar Pustaka}

Dendy; Sukma Bharata, A. (2010). Ayo Bikin Iklan: Memahami Teori \& Praktek Iklan Media Lini Bawah. Jakarta : PT Elex Media Komputindo.

Durianto, D; Widjaja, S. (2003). Inovasi Pasar dengan Iklan yang Efektif. Jakarta : Gramedia.

Green, J. (2012). Advertising. NY : The Rosen Publishing Group.

Jaiz, M. (2014). Dasar-dasar Periklanan. Yogyakarta : Graha Ilmu.

Kasali, R. (1993). Manajemen Periklanan. Jakarta : Grafiti.

Moriarty, S; Mitchell, N; Wells, W. (terj. Tri Wibowo). (2010). Advertising. Jakarta : Prenada Kencana.

Lado Cousté, N.; Martos-Partal, M; Martínez-Ros, E. 2012. The Power of a Package

Product. Journal of Advertising Research. 2 (3).

Raum, E. (2015). Let's Think about the Power of Advertising. London : Raintree

Sardar, Z.; Van Loon, B. (2008). Membongkar Kuasa Media. Magelang : Resist Book.

Shimp. (2010). Advertising Promotion and Other Aspects of Integrated Marketing

Communications. USA : Cengage Learning.

Suwardi, P. (2006). Seputar Bisnis dan Produksi Siaran Televisi. TVRI Sumbar. 